\title{
Pemberdayaan Usaha Sambal Kemasan
}

Fitra Mardiana $^{1}$,Trisa Indrawati ${ }^{2}$, Suprayoga $^{3}$

Fakultas Ekonomi dan Bisnis Universitas Wijaya Putra

fitramardiana@uwp.ac.id, trisaindrawati@uwp.ac.id, suprayoga@uwp.ac.id

\begin{abstract}
Abstrak
Program kegiatan ini bertujuan untuk mengembangkan manajemen usaha serta meningkatkan produksi pada usaha mikro Sambal Kemasan di Kelurahan Semimi Kecamatan Benowo. Target Luaran yang telah dicapai meliputi : 1) mitra dapata meningkatkan produksi, 2) mitra memiliki pengetahuan tentang cara penjualan produk dengan memanfaatkan media sosial ,3) mitra memiliki kemampuan untuk menyusun administrasi pembukuan keuangan sederhana, Metode yang digunakan dalam Program Pemberdayaan Masyarakat ini adalah 1) pelatihan 2) pendampingan usaha mikro sambal kemasan serta 3) melakukan monitoring, evaluasi dan pelaporan terhadap hasil kegiatan dan keberhasilan program yang telah ditetapkan. Dampak dari pelaksanaan kegiatan ini yaitu meningkatnya jumlah produksi dan cara penjualan produk dengan kemasan yang bersih dan menarik dengan memanfaatkan media sosial.
\end{abstract}

Kata Kunci : Sambal Kemasan, peningkatan produksi, media sosial

\section{PENDAHULUAN}

UKM merupakan salah satu pilar utama perekonomian nasional yang berwawasan kemandirian memilikii potensi besar untuk meningkatkan kesejahteraan. Sebagai kelompok usaha kecil, ditemukan permasalahan terkait UKM yang dialami oleh UKM antara lain : 1) kurang / keterbatasan modal, 2) kesulitan dalam pemasaran, 3) persaingan usaha yang ketat, 4) kesulitan bahan baku, 5) kurang teknik produksi, keahlian 6) kurang ketrampilan manajerial 7) kurang memahami manajemen keuangan, 8) iklim usaha (perizinan, aturan perundang-undangan) yang kurang kondusif. Menurut Kuncoro UKM perlu diarahkan untuk meningkatkan kemampuan pengusaha kecil menjadi pengusaha menengah dan pengusaha mikro menjadi usaha kecil. Namun tantangan UKM juga masih terjadi seperti kendala kemampuan, ketrampilan, keahlian, manajemen sumberdaya manusia, informasi pemasaran dan pencatatan keuangan. Usaha Kecil Menengah menjadi salah satu pilar ekonomi nasional. UKM juga diharapkan mampu berperan dan berfungsi sebagai katup pengaman untuk menyediakan alternatif kegaiatan produktif, alternatif penyaluran kredit maupun dalam hal penyerapan tenaga kerja. Salah satu upaya untuk meningkatkan kemampuan usaha kecil diperlukan pelatihan, pembinaan yang berkelanjutan dan pendampingan. Hal ini dilakukan agar UKM memiliki kualitas produk yag lebih unggul. Salah satu UKM yang berkembang produk sambal kemasan.

Masyarakat Indonesia suka dengan masakan atau makanan yang bercita rasa pedas. Masakan pedas memang menjadi salah satu cii khas kuliner di Indonesia. Sambal disukai karena menyajikan rasa yang pedas dan mampu menggetarkan lidah. Umumnya sambal memang disukai dari anak anak hingga orang

$$
\text { Ekonomi, Sosial dan Budaya }
$$

1206 
tua. Sambal memang ada berbagai macam jenis. Cara membuat sambalpun cukup mudah. Begitupun dengan sambal kemasan yang membuat sambal lebih praktis dan mudah untuk dikonsumsi. Sambal kemasan memang lagi hits dan tengah digandrungi oleh masyarakat. Dimana saja, kapan saja dan dimana saja sangat mudah untuk menikmati sambal. Sambal dalam bentuk kemasan dipilih lantaran sangat praktis dan tidak ribet tentunya dan bisa disimpan lagi jika sambalnya tidak habis. Permintaan sambal kemasan terus meningkat dari waktu ke waktu. Tingginya permintaan sambal memberikan peluang bisnis yang menjanjikan. Sambal meskipun kerap dianggap sepele karena hanya sebagai cocolan saat makan, ternyata memiliki kandungan gizi yang tinggi, termasuk kandungan serat dan cairan. Secara umum buah cabe yang merupakan bahan utama pembuatan sambal ini mempunyai banyak kandungan gisi yang baik dalam bentuk segar maupun kering. Dalam setiap 100 gram bahan cabe merah besar mengandung energi $318 \mathrm{kkal}$, air $8.05 \mathrm{mg}$, protein $12.01 \mathrm{mg}$, karbohidrat $56,63 \mathrm{mg}$, serat 27,20 mg, kalsium (Ca) 148,00 mg , besi (fe) $7,80 \mathrm{mg}$, vitamin C 76,40 $\mathrm{mg}$, thiamin $0.33 \mathrm{mg}$, riboflavin $0.92 \mathrm{mg}$, vitamin A 41.61 SI, vitamin E 29,83 mg (Anonim, 2014). Sedangkan dalam satu porsi sambal, kurang lebih 5 sendok makan sambal terdapat 60 gram kandungan cairan serta 1 gram serat. Hal ini akan memberikan asupan cairan dan serat untuk kebutuhan harian tubuh. Tomat dan cabai keduanya memiliki kandungan vitamin $\mathrm{C}$ dan $\mathrm{A}$ yang tinggi, utamanya jika dipilih yang sudah berwarna merah atau orange. Hal ini memberikan manfaat untuk tubuh berupa imunitas tubuh serta pemenuhan vitamin A.

Berdasarkan pengamatan yang dilakukan oleh Tim terhadap mitra ditemukan permasalahan yang dihadapi mitra yaitu :

\begin{tabular}{|l|l|l|l|}
\hline No & \multicolumn{1}{|c|}{$\begin{array}{c}\text { Aspek } \\
\text { Permasalahan }\end{array}$} & \multicolumn{1}{|c|}{ Permasalahan } & \multicolumn{1}{c|}{ Solusi } \\
\hline 1. & $\begin{array}{l}\text { Pengelolaan } \\
\text { Produksi }\end{array}$ & $\begin{array}{l}\text { Keterbatasan alat produksi } \\
\text { produk tidak tahan lama, sambal } \\
\text { kemasan bisa bertahan sekitar 7 } \\
\text { hari. } \\
\text { Belum ada masa kedaluwarsa } \\
\text { dalam kemasan produk } \\
\text { Alat yang dipergunakan untuk } \\
\text { produksi masih sederhana }\end{array}$ & $\begin{array}{l}\text { - Ada alat tumbuk untuk } \\
\text { mempercepat proses produksi } \\
\text { - Pemilihan bahan baku yang } \\
\text { mempunyai kualitas bagus } \\
\text { - Pelathan pengemasan produk } \\
\text { higienis } \\
\text { - uji coba di Laboratorium Sains } \\
\text { UWP }\end{array}$ \\
\hline 2 & $\begin{array}{l}\text { Pembukuan } \\
\text { Sederhana }\end{array}$ & $\begin{array}{l}\text { Belum ada pembukuan sederhana } \\
\text { untuk melihat perkembangan usaha }\end{array}$ & $\begin{array}{l}\text { Pelatihan dan pendampingan } \\
\text { pembukuan sederhana }\end{array}$ \\
\hline 3 & Pemasaran & $\begin{array}{l}\text { Pemasaran masih sederhana yaitu } \\
\text { dari mulut ke mulut, Belum ada } \\
\text { pengembangan pemasaran secara } \\
\text { offline (dengan brosur dan } \\
\text { penambahan konsinyasi) dan belum } \\
\text { menggunakan media online }\end{array}$ & $\begin{array}{l}\text { Pelatihan dan pembuatan label merk, } \\
\text { pendaftaran PIRT, dan system } \\
\text { pemasaran online }\end{array}$ \\
\hline
\end{tabular}

Tujuan yang akan dihasilkan dalam program ini adalah 1) Mitra mampu meningkatkan produksi setelah ada alat bantu, 2) Mitra sudah menyajikan sambel kemasan dengan kemasan yang menarik, 3) Mitra dapat melakukan pemasaran dengan memanfaatkan media sosial, 4)Mitra mengetahui cara pembukuan.

Dengan adanya kegiatan ini diharapkan dapat memberikan manfaat bagi mitra yaitu meningkatkan produksi sambal kemasan terutama dengan adanya kemasan yang lebih menarik. dan diharapkan akan menambah varian sambal yang sudah ada sebelumnya. Mitra juga dapat melakukan pemasaran secara online dengan memanfaatkan media sosial.

\section{METODE}

Metode yang digunakan adalah pendampingan dan pelatihan terhadap mitra. Rencana yang akan dilakukan oleh adalah sebagai berikut :1) Bidang Produksi, tim akan memberikan saran dan uji coba dan konsultasi/ tes laboratorium di Lab Sains Universitas Wijaya Putra bekerjasama dengan Dosen Fakultas Pertanian Universitas Wijaya Putra. Selain itu tim akan memberikan blander atau alat tumbuk untuk mempercepat proses produksi. Selain itu dengan pendampingan untuk pemilihan bahan dan proses produksi yang higienis. dari narasumber yang kompeten di tempat mitra, 2) Penncatatan keuangan, tim akan memberikan Pelatihan dan Pendampingan Pembuatan Pembukuan Sederhana untuk mengetahui perkembangan usaha.3) Bidang Pemasaran, tim akan melakukan pendampingan dalam membuat label agar lebih menarik dan praktis dengan 
menggunakan brand yang sudah ada. Tim juga akan melakukan pendampingan pada saat melalukan pemasaran secara offline dan online agar jangkauan pasar mereka lebih luas. Secara Offline produk tersebut akan dibuatkan brosur untuk dititipkan di warung, koperasi atau minimarket. sedangkan secara online akan dilakukan dengan melalui market place. Untuk pemasaran online dengan Pelatihan dan pendampingan IT yang melibatkan mitra. Dengan demikian maka pendapatan mitra akan meningkat dan akan meningkatkan pula kesejahteraan.

\section{HASIL DAN PEMBAHASAN}

Aktifitas program PPM ini secara garis besar dibedakan menjadi 3 (tiga) tahap yaitu tahap persiapan, tahap pelaksanaan dan tahap evaluasi. Kegiatan dalam tahap pra-pelaksanaan adalah kegiatan yang dilakukan sebelum dilaksanakannya kegiatan utama dari program PPM ini, yaitu koordinasi dengan tim pengusul dengan mitra untuk mengetahui permasalahan yang dihadapi dan solusi yang ditawarkan kepada mitra.

Adapun tahapannya sebagai berikut :

1) Tahap Persiapan. Sebelum dilaksanakan kegiatan utama berupa pelatihan dan penyuluhan pembuatan sambal kemasan yang higienis dan peningkatan produksi. Kegiatan pelatihan tentang pemilihan bahan dan uji laboratorium untuk melihat ketahanan masa produksi, dilakukan di fakultas pertanian Universitas Wijaya Putra pada tanggal 11 Juli 2020.

2) Tahap Pelaksanaan : Pada tahap ini dilakukan pelatihan penggunakan alat produksi. Pada tanggal 1 Agustus 2020 mitra dibelikan alat untuk membantu mempercepat proses produksi. Sebelum ada alat dalam satu kali produksi, sambal yang bisa produksi hanya sekitar 15 botol. Namun dengan adanya alat pencacah bawang dan cabe ada peningkatan jumlah produksi. Saat ini dalam satu kali produksi dapat dihasilkan sekitar 27-30 botol. Sehingga kenaikan produksi hampir 100\%.

Proses Pembuatan sambal kemasan
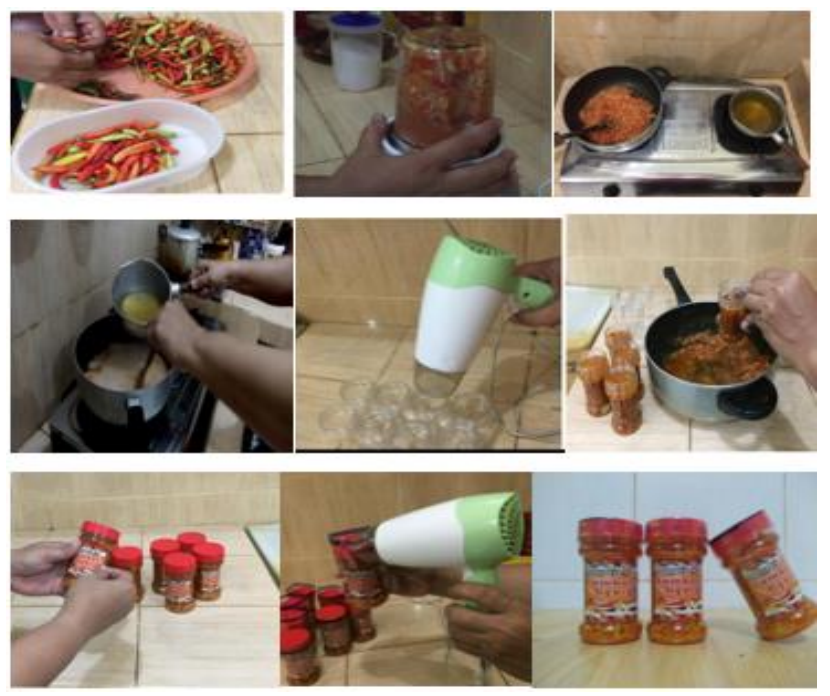

Proses pembuatan dimulai dari pemilihan bahan yang berkualitas bagus, cuci bersih dan ditiriskan sampai tidak ada kandungan air. Panaskan minyak masukkan bahan yang sudah dicuci. Jika sudah layu angkat, tiriskan kemudian haluskan lagi. Panaskan minyak, bahan yang sudah dihaluskan tambahkan minyak panas, aduk kira kira sampai setengah jam. Sebelum dimasukkan dalam botol kemasan pastikan bahwa sambal sudah benar-benar dingin. Beri label dan siap untuk dipasarkan.

Pada tahap ini mitra telah dapat menaikkan hasil produksi dengan kemasan sudah ada label menarik, selain itu sistem pemasaran produk sudah dilakukan secara online dan media sosial . Tahap ini juga memberi pelatihan pada mitra untuk membuat pembukuan sederhana.

3) Tahap Evaluasi Monitoring dan Evaluasi dalam program ini sangat diperlukan untuk melihat keberlangsungan terhadap program yang telah dilakukan. Kegiatan ini dilakukan setalah berakhirnya program. Evaluasi dan monitoring dilakukan setiap 3 (tiga) sekali. Dengan dilakukannya kegiatan monitoring dan evaluasi terhadap pelaku usaha sekaligus menjadi sarana belajar dan proses mengupgrade diri sehingga dapat ditemukan hal baru dan strategi baru untuk meningkatkan produksi.

Dengan demikian hasil akhir dari kegiatan pengabdian ini adalah mitra telah dapat menaikkan hasil produksi dengan telah adanya label pada hasil produksi. Pendampingan berupa cara pemasaran

Ekonomi, Sosial dan Budaya

1208 
dengan memanfaatkan media sosial diharapkan dapat meningkatkan penjualan. Selain itu mitra sangat terbantu dengan adanya pelatihan penyusunan pembukuan sederhana, karena selama ini tidak ada catatan pembukuan.

\section{KESIMPULAN}

Dengan adanya kegiatan pelatihan dan pendampingan pada mitra dapat meningkatkan produksinya sehingga bisa memiliki daya saing di pasaran, dan mitra juga bisa memanfaatkan media sosial untuk meningkatkan penjualan.

\section{SARAN}

Agar pelanggan tidak bosan dengan satu jenis produk, maka mitra harus membuat beberapa varian baru. Banyaknya varian sambal akan memudahkan pelanggan untuk menentukan pilihan yang disukai. Selain itu mitra harus mengikuti perkembangan usaha agar tidak ketinggalan dalam mengembangkan produk, sehingga produk selalu dinanti oleh pelanggan.

\section{UCAPAN TERIMAKASIH (Bila ada)}

Ucapan terimakasih disampaikan kepada Universitas Wijaya Putra, khususnya LPPM yang telah memberikan support dalam pelaksanaan kegiatan pengabdian kepada masyarakat.

\section{REFERENSI}

Azizah Nur, A, Pramono Budi, 2018.Sifat Organoleptik Sambal Pecel UKM $\mathrm{Hj}$
Sartinah Semarang Selama masa Penyimpanan, Jurnal Teknologi Pangan, Volume 3, 2018, www.ejournals1.undip.ac.id/index.php/tekpangan. eISSN 2597-9892

Putra, Steven Soesanto,2019,.Pengaruh Perbedaan Bahan Pengemas Terhadap Umur Simpan, Karakteristik Fisikokimia, dan Organoleptik Pada Dua Jenis Sambal, Skripsi. Program Studi Teknologi Pangan, Fakultas Teknologi Pertanian, Universitas Katolik Soegijapranata, Semarang.

Rokilah, Prarudiyanto A, Werdiningsih W, 2018, Pengaruh Kombinasi Kemasan dan Masa Simpan Terhadao Beberapa Komponen Mutu Bumbu Plecingan Instan. Jurnal Ilmiah Rekayasa Pertanian dan Biosistem, Volume 6 No. 1 Maret 2018.

Sulistyo.2010.Pengembangan Usaha Kecil Menengah dengan Basis Ekonomi Kerakyatan di Kabupaten Malang.No 01.Vol 06.Jurnal Ekonomi Modernisasi.Universitas Kanjuruhan Malang 